\title{
The Discovery and Function of Filaggrin
}

\author{
J. Kenneth Hoober *(D) and Laura L. Eggink
}

check for

updates

Citation: Hoober, J.K.; Eggink, L.L. The Discovery and Function of Filaggrin. Int. J. Mol. Sci. 2022, 23, 1455. https://doi.org/10.3390/ ijms23031455

Academic Editor: Naoko Kanda

Received: 14 December 2021

Accepted: 26 January 2022

Published: 27 January 2022

Publisher's Note: MDPI stays neutral with regard to jurisdictional claims in published maps and institutional affiliations.

Copyright: (C) 2022 by the authors. Licensee MDPI, Basel, Switzerland. This article is an open access article distributed under the terms and conditions of the Creative Commons Attribution (CC BY) license (https:// creativecommons.org/licenses/by/ $4.0 /)$.

\author{
Susavion Biosciences, Inc., 1615 W University Drive, Suite 132, Tempe, AZ 85281, USA; \\ Laura.eggink@susavion.com \\ * Correspondence: jkhoober@susavion.com; Tel.: +1-480-921-3795
}

\begin{abstract}
Keratohyalin granules were discovered in the mid-19th century in cells that terminally differentiate to form the outer, cornified layer of the epidermis. The first indications of the composition of these structures emerged in the 1960s from a histochemical stain for histidine, followed by radioautographic evidence of a high incidence of histidine incorporation into newly synthesized proteins in cells containing the granules. Research during the next three decades revealed the structure and function of a major protein in these granules, which was initially called the 'histidine-rich protein' Steinert and Dale named the protein 'filaggrin' in 1981 because of its ability to aggregate keratin intermediate filaments. The human gene for the precursor, 'profilaggrin,' was reported in 1991 to encode 10, 11 or 12 nearly identical repeats. Remarkably, the mouse and rat genes encode up to 20 repeats. The lifetime of filaggrin is the time required for keratinocytes in the granular layer to move into the inner cornified layer. During this transition, filaggrin facilitates the collapse of corneocytes into 'building blocks' that become an impermeable surface barrier. The subsequent degradation of filaggrin is as remarkable as its synthesis, and the end-products aid in maintaining moisture in the cornified layer. It was apparent that ichthyosis vulgaris and atopic dermatitis were associated with the absence of this protein. McLean's team in 2006 identified the cause of these diseases by discovering loss-of-function mutations in the profilaggrin gene, which led to dysfunction of the surface barrier. This story illustrates the complexity in maintaining a healthy, functional epidermis.
\end{abstract}

Keywords: keratohyalin granules; histidine-rich protein; filaggrin; profilaggrin; loss-of-function mutations; ichthyosis vulgaris; atopic dermatitis; eczema; corneodesmosomes; transglutaminase

\section{Keratohyalin Granules and Histidine}

Karen Holbrook [1] commented that "morphology is often the starting point of an investigation". Developments in microscopy during the 19th century opened morphology of the cellular world to full view. The ability to thin-section fixed tissues and innovations in selectively staining cellular components provided biologists with opportunities to study structures of tissues and the organelles within cells. This brief historical review starts with several striking observations made by histochemical and radioautographic analyses of the epidermis, which, as the story is told, led to the discovery of filaggrin and its short-lived but essential functions in the assembly of a healthy surface barrier.

A fascinating morphological feature forms under the cornified layer of the epidermis (Figure 1) as keratinocytes move outward from the proliferative basal layer and terminally differentiate into corneocytes that form the surface barrier of the skin. Stephen Rothman [2], recounting the early history of studies on these 'keratohyalin granules', remarked that during those slower years of "wax candles and horse carriages", there was time for "detailed and precise observations that revealed the existence of granules in the granular layer, [which were] first observed and recorded by Auffhammer (1869)". The granules were further studied by Langerhans (1873) and designated 'keratohyalin' in 1882 by Waldeyer. Although very active in research on the skin throughout his career, Rothman commented shortly before he died in 1963 that not much more had been learned since those early days [3]. He 
did not live to see the dramatic developments that emerged from the investigations of these unusual structures that were already underway in several laboratories.

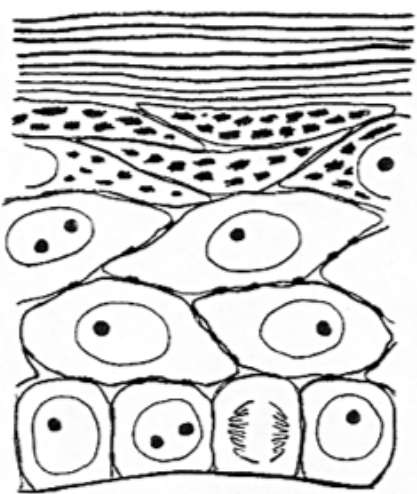

\section{Cornified Layer (Stratum Corneum) \\ Granular Layer (Stratum Granulosum)}

Spinous Layer (Stratum Spinosum)

Basal Layer (Stratum Basale)

\section{Dermis}

Figure 1. A sketch of the epidermis of the newborn rat [4].

Seminal observations were published in the years following 1960. Reaven and Cox [5,6] traced the accumulation of zinc in the granular layer to chelation by the high density of histidine in the keratohyalin granules [7]. The granules stained an intense red color with diazotized sulfanilic acid under alkaline conditions, a coupling reaction developed by Pauly [8] for histidine (Figure 2A). Kimie Fukuyama, while a visiting scientist in I. A. Bernstein's laboratory at the University of Michigan, began investigations of the epidermis by the incorporation of radiolabeled nucleotides into DNA and then into RNA by radioautography. She observed that, whereas DNA was synthesized only in the basal layer, incorporation of precursors into RNA occurred throughout the layers below the stratum corneum $[9,10]$, which suggested that proteins were also synthesized in the outer layers. The surprise came when she turned to the incorporation of $\left[{ }^{3} \mathrm{H}\right]$ amino acids. As expected, labeled phenylalanine, leucine and methionine were extensively incorporated into the dividing cells of the basal layer but minimally in the outer layers. Conversely, $\left[{ }^{3} \mathrm{H}\right]$ histidine and $\left[{ }^{3} \mathrm{H}\right]$ glycine were preferentially incorporated into the granular layer (Figure 2B) [11-13]. The possibility of synthesis of a unique protein exclusively in the granular layer while the cells are undergoing terminal differentiation was proposed by Bernstein, who had become interested in the epidermis as a tissue to study the process of differentiation [14]. This hypothesis called for a deeper analysis, which could only be resolved by purification of a protein enriched in histidine and glycine.
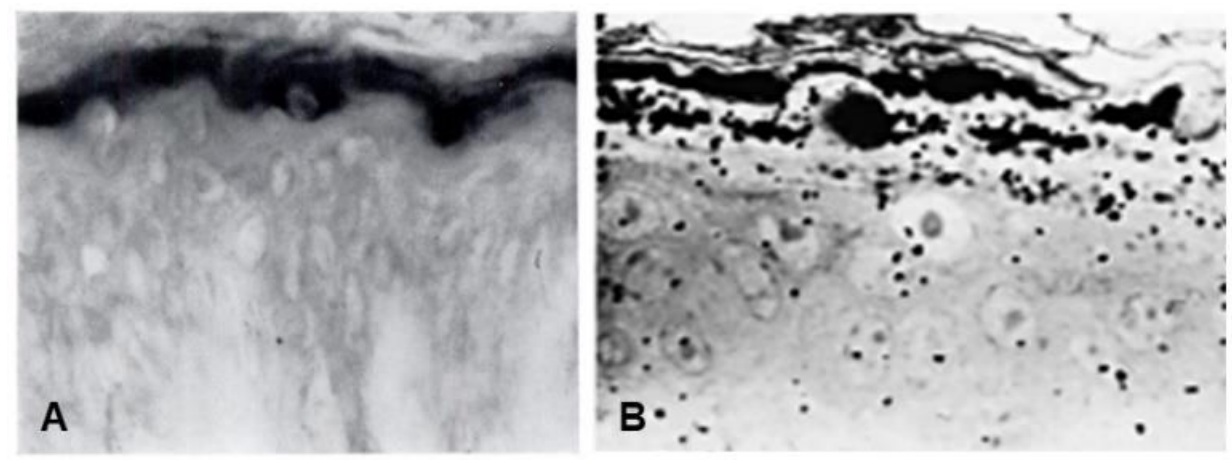

Figure 2. (A) Human skin stained with the Pauly reagent for histidine [5]. (B) Light microscopic radioautograph of newborn rat epidermis $15 \mathrm{~min}$ after intraperitoneal injection of $\left[{ }^{3} \mathrm{H}\right]$ histidine [12].

\section{Discovery of the 'Histidine-Rich' Protein}

This goal was accomplished in Bernstein's laboratory by one of the authors (JKH) while a graduate student. A protein fraction was extracted from isolated epidermis of 
newborn rats that contained several-fold more histidine, and a five- to six-fold greater specific radioactivity from injected $\left[{ }^{3} \mathrm{H}\right]$ histidine or $\left[{ }^{3} \mathrm{H}\right]$ glycine, than the remaining bulk protein $[15,16]$. Subsequent graduate students and postdoctoral fellows continued to refine the study of this protein fraction, which became known as the 'histidine-rich protein (HRP)' and was definitively localized to the granular layer by dissociation of the lower layers of the epidermis with tetraphenylboron [17]. Extraction of the granular and cornified layers with $8 \mathrm{M}$ urea, dialysis, lyophilization and extraction of the dried material with $0.1 \mathrm{~N}$ perchloric acid followed by precipitation at $\mathrm{pH} 4.5$ (the protocol developed by Hoober [4]) yielded a basic protein fraction that contained $7 \%$ histidine, $12 \%$ arginine, $16 \%$ serine and $14 \%$ glycine [16-18]. The puzzling observation that $8 \mathrm{M}$ urea was required for extraction of a protein inherently water soluble because of the high content of polar amino acids would become clear many years later. Ball et al. [19] prepared a high molecular weight HRP from the granular layer that was converted to a smaller form in the stratum corneum, with kinetics of an apparent precursor/product relationship. Ugel $[20,21]$ extracted proteins from bovine hoof epidermis with $1 \mathrm{M}$ potassium phosphate, $\mathrm{pH}$ 7.0, which when dialyzed formed aggregates similar to keratohyalin granules. Application of this technique to newborn rat epidermis generated keratohyalin granule-like structures that contained HRP, thereby providing definite evidence for localization of this protein in the granules [22]. Electrophoresis of proteins in the granules revealed a main fraction with a mass of $46.5 \mathrm{kDa}$. In a study of mouse epidermis, Balmain et al. [23] found that histidine-rich proteins with a range of $70 \mathrm{kDa}$ to $120 \mathrm{kDa}$ were rapidly synthesized in vitro, whereas a $27 \mathrm{kDa}$ protein appeared simultaneously with the production of mature keratohyalin granules in fetal epidermis [24]. Interestingly, the high concentration of histidine detected by the Pauly reaction did not persist as the cells moved into the cornified layer $[5,6,17]$. Likewise, $\left[{ }^{3} \mathrm{H}\right]$ histidine that was incorporated into proteins that were synthesized in the granular layer was lost as the cells moved outward [12,19], which suggested that the protein was degraded to soluble products.

The biochemical work on keratohyalin granules that began in Bernstein's laboratory had revealed the unusual composition of HRP, and, combined with the unconventional protocol for purification of the protein, initiated a path of research that led to characterization of a "remarkable" protein, as described by Brown and McLean [25]. Beverly Dale introduced purification of epidermal proteins by ion-exchange chromatography in $4 \mathrm{M}$ urea, with which she obtained a 'basic protein' with properties similar to HRP [26]. Steinert, Dale and their colleagues [27] succeeded in further purifying the protein to homogeneity in $8 \mathrm{M}$ urea, with final steps in dilute formic acid, from newborn mouse and rat epidermis. The mouse and rat proteins were estimated by gel electrophoresis to have masses of $30 \mathrm{kDa}$ and $48 \mathrm{kDa}$, respectively. However, equilibrium sedimentation in $6 \mathrm{M}$ guanidine hydrochloride yielded masses of $25.8 \mathrm{kDa}$ and $38.4 \mathrm{kDa}$, respectively. The purified basic proteins, with a pI greater than $\mathrm{pH} 9.5$ [26-28], contained about $8 \%$ histidine and 12 or $14 \%$ arginine, but little, if any, lysine, valine, leucine, tyrosine, phenylalanine or tryptophan and no cysteine or methionine.

Peter Steinert and colleagues had extensively studied the intermediate filaments of keratin [29]. When these filaments were prepared from subunits purified from mouse, bovine and hamster tissues and mixed with HRP purified from mouse stratum corneum, a rapid increase in turbidity occurred with formation of macrofibrils. Analysis of these complexes revealed $2 \mathrm{~mol}$ of HRP per $3 \mathrm{~mol}$ of keratin intermediate filament subunits. Control experiments showed that the basic protein did not interact specifically with F-actin or tubulin. These findings were the first demonstration of the function of HRP, and Steinert, Dale, and their colleagues bestowed upon the protein the name 'filaggrin' (fil-ăg'-grin) for its ability to aggregate keratin intermediate filaments [27]. In contrast to filaggrin, keratin is synthesized in cells of the basal and spinous layers and becomes the bulk of the protein content in corneocytes [30]. 


\section{Discovery of the Precursor, Profilaggrin}

Incorporation of labeled histidine into an immunologically cross-reactive, high-molecular-mass protein $(>300 \mathrm{kDa})$ revealed that filaggrin was synthesized as a large precursor and processed to smaller units [19,31]. In 1980, Lonsdale-Eccles et al. [32] reported purification of a partially processed, basic protein from the stratum corneum of newborn rats that had a $\mathrm{pI}$ as low as $\mathrm{pH}$ 6.9. The low $\mathrm{pI}$ resulted from 15 to $20 \mathrm{~mol}$ of covalently bound phosphate per mol of the protein. A precursor/product relationship between the high-molecular-weight protein and the smaller, monomeric HRP was shown by incorporation of $\left[{ }^{3} \mathrm{H}\right]$ histidine and $\left[{ }^{32} \mathrm{P}\right]$ orthophosphate into newly synthesized proteins in punch biopsies of human skin. At the end of a 1-h labeling period, a high-molecular-mass $(>200 \mathrm{kDa})$ protein was labeled with both isotopes. After a 15-h chase, the $37 \mathrm{kDa}$ monomer contained nearly all the $\left[{ }^{3} \mathrm{H}\right]$ histidine but none of the $\left[{ }^{32} \mathrm{P}\right]$ orthophosphate [33]. Thus, the precursor was extensively phosphorylated after synthesis in the granular layer of the epidermis, presumably to prevent premature association with, and aggregation of, keratin filaments, but as the cells differentiated into corneocytes, the protein was dephosphorylated and processed to monomers. The unique function of filaggrin in the specific aggregation of intermediate filaments led in 1985 to naming the high-molecular-mass precursor 'profilaggrin' [33]. The hypothesis that the gene for profilaggrin consists of tandem repeats separated by short linker sequences was demonstrated in 1986 by Haydock et al. [34] and in 1987 by Rothnagel et al. [35] from sequence analysis of cDNA clones for mouse and rat profilaggrin.

In 1989, Steinert's research team at the National Institutes of Health, in collaboration with Bernstein at the University of Michigan, Croce at Temple University, Parry at Massey University and Lessin at the University of Pennsylvania, published the partial structure of the human profilaggrin gene, which contained 12 repeating units [36]. The nucleotide and deduced amino acid sequences showed that each repeat contains 324 amino acids, with considerable sequence variation among the repeats. Each repeat of the human protein is separated by a conserved linker of seven amino acids with the sequence FLYQVST [36], whereas the rat and mouse profilaggrins have linkers that contain the sequence VYYY [37]. Cleavage of the protein and trimming of the linker provide filaggrin monomers with 317 amino acids and a mass of $37 \mathrm{kDa}$. Gan et al. [38] showed that the gene encoding this polyprotein in humans contains 10,11 or 12 repeats and that different individuals may contain one or two of these three genes, among the two copies each person carries, because of allelic differences. As deduced from the cDNA sequence, the human protein contains $12 \%$ histidine, $10 \%$ arginine, $15 \%$ glycine and $25 \%$ serine [36]. The high content of serine provides ample sites for phosphorylation. In situ hybridization with antisense RNA probes exclusively decorated cells in the granular layer, which confirmed that profilaggrin mRNA is transcribed only as keratinocytes differentiate into corneocytes [35,36]. Completion of the structure of the gene was accomplished by analysis of the $5^{\prime}$ - and $3^{\prime}$-regions $[39,40]$, which revealed an S-100-like N-terminal domain that contains two EF-hand sequences that bind $\mathrm{Ca}^{2+}$. The full-length protein described in the National Center for Biotechnology Information contains 4061 amino acids, with a mass of $435,170 \mathrm{Da}$, which accommodates 10 filaggrin units. Figure 3 illustrates the structure of the human profilaggrin gene.

Remarkably, the mouse [41] and rat [42] profilaggrin genes were found to contain 20 repeats. Nearly equal amounts of two different, randomly arranged repeats, 250 and 255 amino acids in length, occur in the mouse protein, and are separated by short linker sequences. The mouse and rat proteins have $60 \%$ homology between the sequences [39], but both have less sequence homology with the human protein. Nevertheless, the compositions of the proteins are similar, with the mouse protein containing $9 \%$ histidine, $12 \%$ arginine, $17 \%$ glycine and $20 \%$ serine [35]. The inclusion of an S-100-like domain in the $\mathrm{N}$-terminus of profilaggrin from all of these species is interesting in light of the requirement for elevated $\mathrm{Ca}^{2+}$ levels for expression of the profilaggrin gene and keratinocyte differentiation [43-45]. $\mathrm{Ca}^{2+}$ binding by these domains may be largely responsible for the peak of the $\mathrm{Ca}^{2+}$ gradient in the granular layer [46]. Given the importance of $\mathrm{Ca}^{2+}$ in the process of cornification, 
Aho et al. [47] found that overexpression of the N-terminal domain surprisingly inhibited expression of profilaggrin and other major proteins required for keratinocyte differentiation. Complete silencing of the profilaggrin gene resulted in hyperproliferation of keratinocytes, which suggested that the S-100-like domains are required to maintain the concentration of free $\mathrm{Ca}^{2+}$ needed for control of these processes.

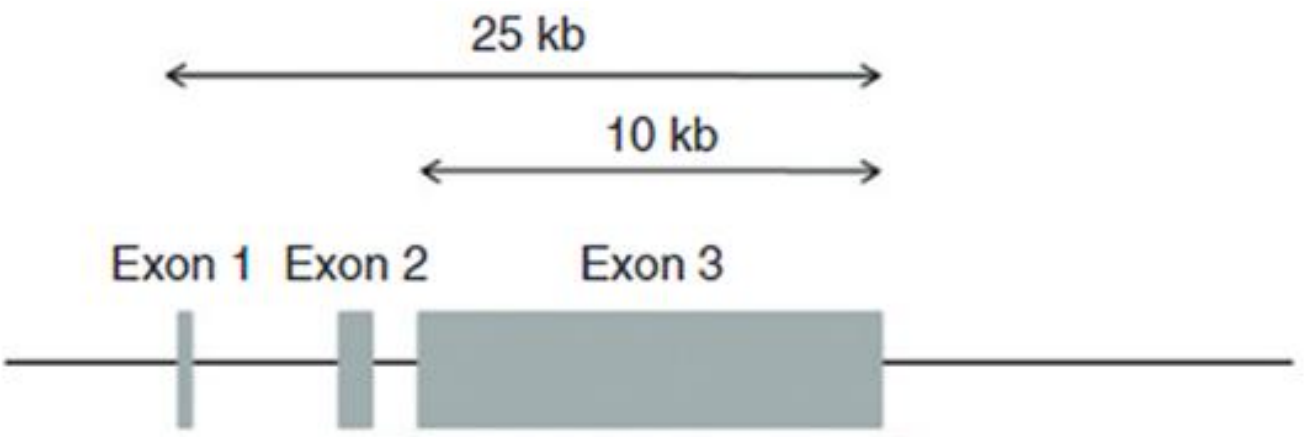

Figure 3. The human profilaggrin gene on chromosome 1q21. Exon 2 contains the translation initiation codon. The entire coding region of the protein is within the uninterrupted exon 3.

\section{The Short Life of Filaggrin}

Upon synthesis, profilaggrin is heavily phosphorylated and is incorporated into keratohyalin granules. As cells of the granular layer move through the transitional zone into the inner layers of the cornified layer, the protein is dephosphorylated, and a complex group of proteases cleaves the precursor into monomeric filaggrin, which binds to keratin intermediate filaments and causes collapse of the cytoplasm into the predominant component of the flattened corneocytes $[25,27,48]$. As the cells move outward, only the first few inner layers of the cornified layer contain filaggrin, whereas the outer layers retain keratin [49]. The absence of histidine by histochemical analysis and $\left[{ }^{3} \mathrm{H}\right]$ from labeled histidine in the outer cornified layers revealed that filaggrin is degraded as corneocytes proceed through the inner layers of the stratum corneum.

A flowchart that illustrates the steps in this process is provided in Figure 4 (see legend for reference numbers). The N-terminal A domain, which contains the $\mathrm{Ca}^{2+}$-binding EF-hand sequences, is cleaved from profilaggrin prior to processing of the remainder of the protein. Skin-specific retrovirus-like aspartic protease (SASPase) cleaves the linker sequences to yield active monomers that bind to keratin intermediate filaments. Knock-out of the serine proteases CAP1/Prss8 and matriptase/MT-SP1 caused incomplete processing of profilaggrin and little, if any, monomeric filaggrin, which suggested that these proteases are also involved in processing profilaggrin to the monomeric form. Upon completing its function in facilitating collapse of keratin filaments, filaggrin is further degraded by calpain 1, caspase 14 and bleomycin hydrolase to free amino acids (Figure 4B). The final mixture of amino acids, along with urocanic acid (UCA) produced by deamination of histidine, 2-pyrrolidone carboxylic acid (PCA) produced by cyclization of glutamine and other metabolic products, have been designated the 'natural moisturizing factor (NMF)' and aid in maintaining hydration of the stratum corneum. The activity of most of these proteases is $\mathrm{Ca}^{2+}$-dependent. 

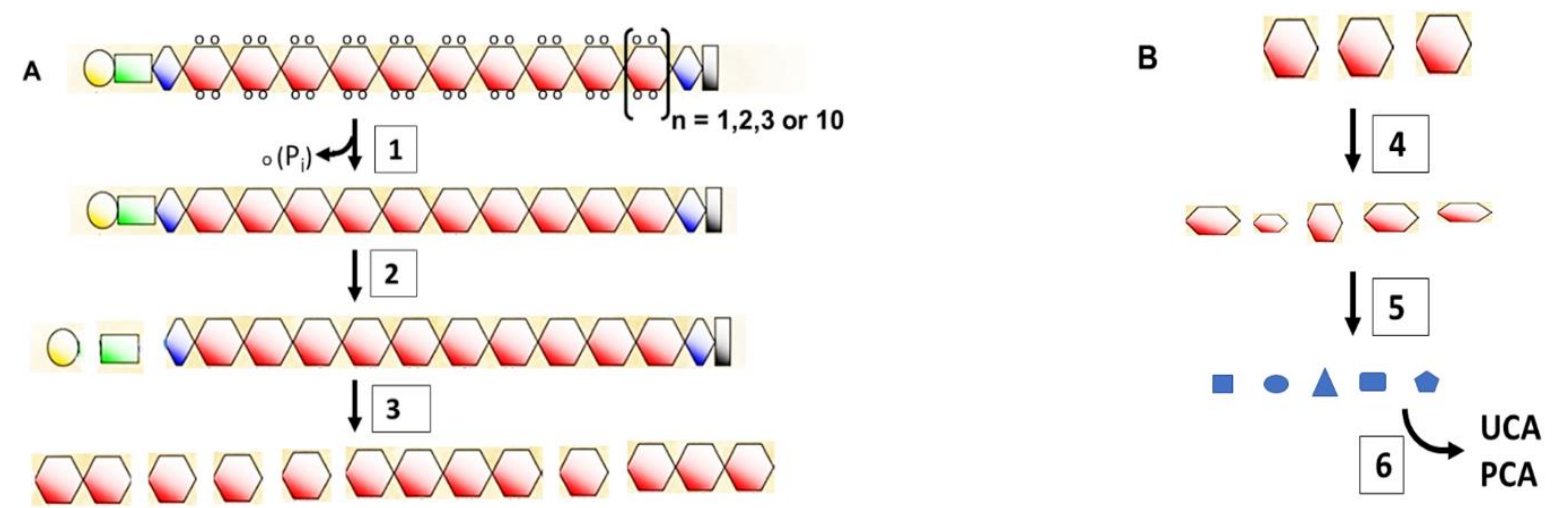

Figure 4. Flowchart of the processing of profilaggrin to free amino acids. (A). Proflaggrin to filaggrin. (1) Phospho-profilaggrin is dephosphorylated by phosphatases. (2) The A (yellow) and B (green) domains are cleaved from profilaggrin by furin, PACE4 (Paired basic Amino acid Cleaving Enzyme 4) and endoproteinase-1 (PEP1) [50,51]. (3) Linker sequences of human profilaggrin (FLYQVST) are cleaved by skin-specific retrovirus-like aspartic protease (SASPase) [52], channel-activating serine protease (CAP1) [53] and matriptase (MT-SP1) [54] to monomeric filaggrin. Aminopeptidases and carboxypeptidases are likely involved in trimming the new termini [37]. (B). Filaggrin to NMF. (4) Arginine residues in filaggrin and keratin are converted to citrulline by peptidylarginine deiminase (PAD1 or 3) [49,55]. Deiminated filaggrin is cleaved by calpain-1 and caspase-14 (at VSQD and HSED sequences) to filaggrin fragments [55-57]. (5) Filaggrin fragments are digested by neutral cysteine protease (bleomycin hydrolase) to amino acids [57]. Aminopeptidases and carboxypeptidases are also likely involved. (6) Histidine is converted by histidine deaminase to trans-urocanic acid (UCA), which has a UV spectrum similar to that of nucleic acids and proteins [58] and provides a natural sunscreen [59]. Glutamine is non-enzymatically converted to 2-pyrrolidone carboxylic acid (PCA). These hydrophilic final products contribute to the moisturizing of the skin $[56,57,60,61]$. Kezic et al. [62] and de Veer et al. [63] provided excellent reviews of proteolytic processing of filaggrin and differentiation of corneocytes.

\section{Mutations That Cause Loss of Filaggrin}

A major discovery published in 2006 revealed the cause of the complete loss of filaggrin in ichthyosis vulgaris and atopic dermatitis (AD), diseases that result from defective formation of the surface barrier [64]. The loosened cornified layer of the skin in these cases allows water to escape and allergens to gain access to internal cells [65]. Irwin McLean's team at the University of Dundee identified mutations in the first repeat in exon 3 of the profilaggrin gene (R501X generates a nonsense stop-codon, and the 2282del4 deletion also results in a stop-codon), thus revealing the genetic cause of these diseases [25,64-66]. The null mutations R501X and 2282del4 are prevalent in European and Asian populations and lead to the complete absence of profilaggrin in homozygous individuals. Within the next 5 years, an extensive mutation map was generated that showed significant differences between European and Asian populations (Figure 5). A recent analysis of 126 patients with atopic dermatologic disorders in Saudi Arabia detected 227 variants, including missense, silent, nonsense, frameshift and noncoding mutations in exon 3 of the profilaggrin gene [67]. Within the decade following the publication by McLean's team in 2006, a nearly a five-fold increase in the number of research articles related to filaggrin appeared in the literature (Figure 6). Several excellent reviews describe the research productivity during this decade [25,68-70]. 


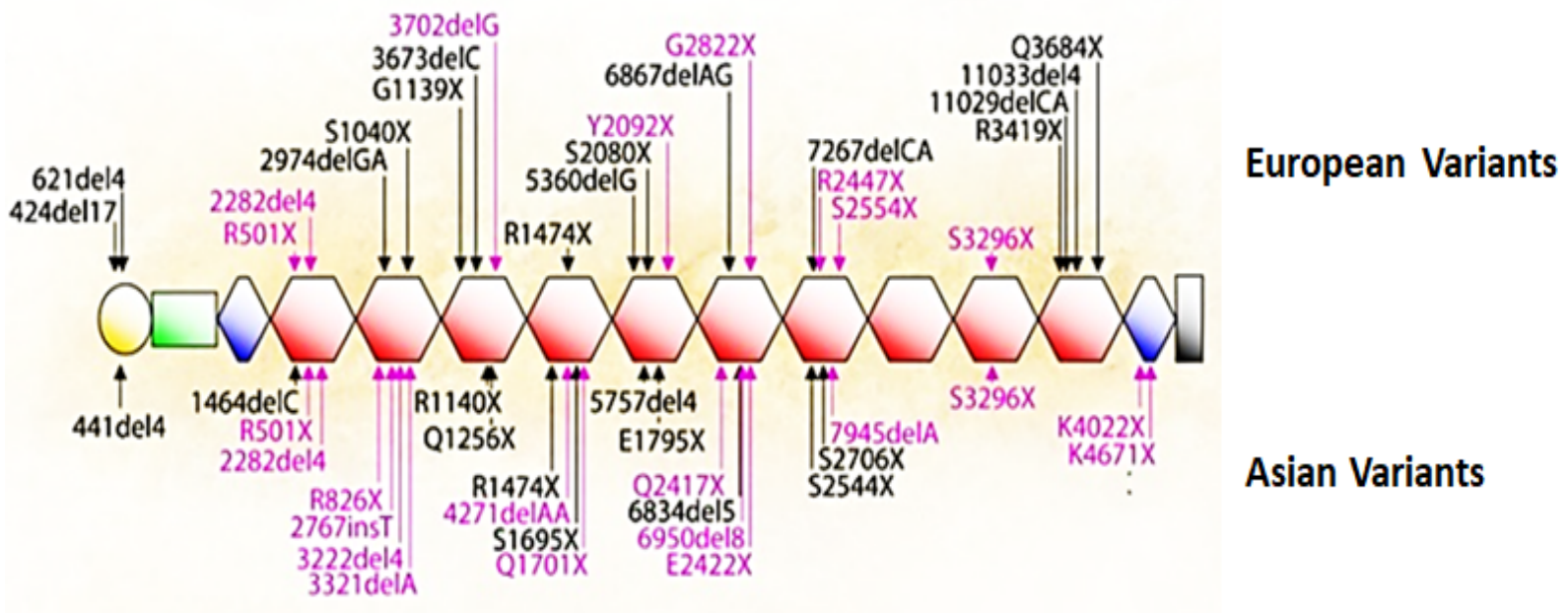

Figure 5. Filaggrin mutations among populations. Mutations that are recurrent in European and Asian populations are indicated in red, and rare or family specific mutations are in black. These mutations are either nonsense mutations or out-of-frame insertions or deletions that are predicted to cause loss-of-function. Exon 3 of the gene contains the complete sequence for profilaggrin, shown here with 10 repeats as orange hexagons. The yellow circle is the S-100-like $\mathrm{Ca}^{2+}$-binding domain, the green rectangle is the B domain, and the blue diamonds are incomplete repeats [65] (with permission from A. D. Irvine).

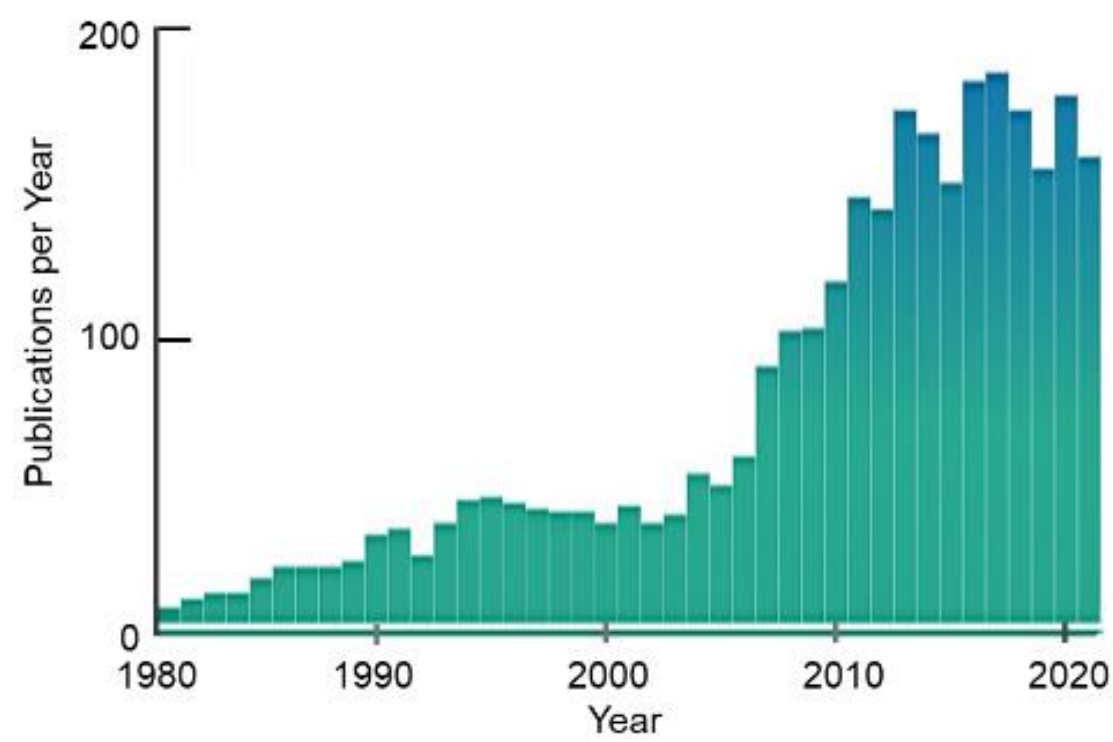

Figure 6. Number of publications that refer to filaggrin as a function of year.

Mutations in the gene encoding profilaggrin are the strongest risk factors for skin diseases. About $50 \%$ of AD patients carry loss-of-function mutations in filaggrin [71] Esparza-Gordillo et al. [72] indicated that $10 \%$ to $20 \%$ of people in industrialized countries suffer from AD (eczema), with a strong disposition in children when the mother carries an FLG mutation. Ichthyosis vulgaris is one of the most common skin diseases, characterized by dry, flaky skin, with a prevalence of at least 1 case per 250 persons. The complexity of these diseases was expanded by Butler et al. [73], who identified twelve distinct diseases within the spectrum of AD. AD is an inflammatory condition, often with open lesions, that affects $14 \%$ of children in the US [74] and up to $25 \%$ in the UK and Scandinavia [75]. AD is the most common chronic skin disease in early childhood and peaks at 2 to 3 years of age, after which it declines to a few percent in adults [75,76]. 
McAleer and colleagues measured the amounts of natural moisturizing factor (NMF) and other degradation products of filaggrin in the skin of $F L G^{+/+}$children as indicators of filaggrin synthesis [76]. The nearly five-fold increase in NMF and a 15-fold increase in free histidine on the cheeks of children during the first 3 years of life indicated that the rate of synthesis of this short-lived protein is quite low after birth, and maturation of the epidermis develops slowly. The immaturity of the skin during this period reveals vulnerability for sensitization to food allergens and other life-long allergies.

Interestingly, defects in processing profilaggrin appear to be more severe than a complete lack of filaggrin. Mice with a deficiency in the protease CAP1 [53] processed profilaggrin to short oligomers but no further, which resulted in an impaired surface barrier, rapid dehydration and death shortly after birth. Pleotropic effects of a deficiency of matriptase/Mt-SP1 also were related to a defect in processing of profilaggrin during cornification of the epidermis, but the minimal processing in these animals seemed to cause less severe disease [54].

A deficiency in filaggrin is not the only cause of AD. Multiple mutations in other genes [71] and also environmental factors [77-79] may cause AD. In fact, the majority of cases of AD have environmental causative or comorbidity factors. Nevertheless, the deficiency of filaggrin has been an instructive case study. Thyssen and Kezic [80] provided an excellent overview of the multifactorial environmental and genetic causes of AD. An extensive review by Dębińska [81] describes treatments for AD currently approved or in clinical trials, with specific focus on factors that regulate expression of the filaggrin gene.

Several animal models of AD have been developed [82,83]. Stout et al. [84] developed an interesting approach to treatment of filaggrin deficiency in the 'flaky tail' strain of mice by linking a recombinant filaggrin monomer to a cell-penetrating peptide derived from the HIV TAT protein. After topical application, the $50 \mathrm{kDa}$ fusion product was processed to a $28 \mathrm{kDa}$ protein, which corresponded to the normally processed filaggrin monomer and restored normal function to mouse skin. Whereas the 'flaky tail' strain is deficient in filaggrin, the protein is not completely absent. Kawasaki et al. [85] generated a homologous recombination vector that eliminated the promoter sequences for mRNA transcription and all ATG start codons for synthesis of this protein, which resulted in complete loss of profilaggrin and a phenotype similar to AD in humans. The condition has also been simulated experimentally by applying a solution of SDS to the skin [86]. With humans, a 24-h treatment with 1\% SDS caused expression of profilaggrin to decrease dramatically but then increase over controls after 4 days post-treatment [87]. Application of $17 \%$ SDS for $7 \mathrm{~h}$ caused the epidermis to become leaky, after which restoration of the surface barrier was studied by measurement of the transepidermal water loss (TEWL) during treatment with ceramide mixtures [88].

Healthy skin requires continual loss of the outer layers by corneocyte desquamation; the outer layers are replaced by dividing cells in the basal layer. However, an excessive loss of corneocytes causes an extreme type of lesional disease similar to AD, known as Netherton syndrome (NS), which results in inflammation and allergic reactions $[89,90]$. NS is a lifethreatening disorder that affects approximately one in 200,000 newborn children [89]. This disease is mediated by kallikrein-related serine peptidases (KLKs), whose normal function is to degrade corneodesmosomes and allow detachment of superficial corneocytes. KLK5 and KLK7 are synthesized as zymogens and activated by cleavage of the precursor forms by mesotrypsin and matriptase [91]. Excessive loss of corneocytes by overactive KLK5 and KLK7 is controlled by the serine protease inhibitor lymphoepithelial Kazai-type-related inhibitor (LEKT1) encoded by the SPINK5 gene. LEKT1 is also degraded by mesotrypsin, which is activated by enteropeptidase in the granular layer [91]. NS is caused by a loss-offunction mutation in the SPINK5 gene, which allows heightened activity of KLKs. Knockout of KLK5 reversed NS symptoms in a SPINK5-deficient mouse model [89-92]. Because of lethality of the Spink5 $5^{-1-}$ knock-out, immunological consequences of the mutation were studied in skin grafts on nude mice. Activation of protease-activated receptor 2 (PAR2), a 
major effector of the inflammatory response, by KLK5 led to recruitment of eosinophilic and mast cells and formation of lesions [92].

Early histological studies found that keratohyalin granules were not present in the epidermis in psoriatic lesions [6,18], and HRP was absent in extracts of these lesions. However, the protein and granules were present in adjacent 'normal' skin [18,19]. Although symptoms of psoriasis are similar to those of $\mathrm{AD}$, mutations in filaggrin are not causative for psoriasis [93,94].

\section{Keratinocyte to Corneocyte Transition}

The context in which filaggrin functions is the transition of keratinocytes to corneocytes. More specifically, this transition involves formation of the cornified envelope and the conversion of cell cytoplasm to an insoluble matrix. Proteins synthesized in the granular layer are organized into a structure, referred to as the 'cornified envelope,' that lines the cytoplasmic surface of the cell membrane [95-98]. Transglutaminases catalyze cross-links between these proteins, which are essential for stabilization of the complex. Three isozymes of the $\mathrm{Ca}^{2+}$-dependent transglutaminase family, TGM1, TGM3 and TGM5, are expressed in the epidermis and function within terminally differentiating keratinocytes [98]. An early step in formation of the cornified envelope is attachment of involucrin to the inner surface of the cell membrane by cross-links catalyzed by the essential enzyme TGM1 [96,98]. Although involucrin contains 39 repeats of a 10-amino-acid sequence, with each containing three glutamine $(Q)$ residues, only one in this 585 -amino acid protein - within the sequence ELPEQQVGQP (the reactive $Q$ is underlined and bold) - is a substrate for TGM1 in vitro unless the protein is proteolytically degraded [99]. Loricrin, an abundant protein that comprises about $80 \%$ of the cornified envelope, is synthesized in cells of the granular layer and forms oligomers with small, proline-rich proteins [100,101]. These complexes are stabilized by TGM3 and then fixed onto the involucrin-containing scaffold by formation of cross-links catalyzed by TGM1 [95]. The keratin filament-filaggrin complex and several minor proteins, such as elafin, are added sequentially to the inner surface of the cell membrane. Keratin and a small amount of filaggrin are cross-linked to loricrin but not to each other [101]. Cross-links, mostly to loricrin, stabilize the cornified envelope and generate the insoluble matrix of corneocytes. Mutations in the TGM1 gene cause the skin disorder lamellar ichthyosis, and $T G M 1^{-1-}$ knockout mice die within a few hours after birth $[96,102]$

Liedén et al. [103] and Su et al. [104] demonstrated a remarkable increase in expression of these transglutaminases in the epidermis of patients with AD. Whereas TGM1 and TGM3 are intracellular enzymes, repair of damage to the epidermis appears to also require extracellular transglutaminase activity. TGM2 is ubiquitously expressed and, unlike other members of the family, is found in the extracellular space [105-108]. Expression of TGM2 is induced in inflamed and wounded tissues [105,109-112] and also by dexamethasone [113]. TGM2 normally occurs in an inactive, closed conformation but is rapidly converted to the open, active form by injury [109,114]. Closure of wounds is significantly impaired in TGM2 knock-out mice [115], and processes required for wound healing and extracellular matrix remodeling are dramatically reduced when fibroblasts and macrophages are rendered TGM2-deficient by transfection with anti-sense RNA [109,110].

\section{Another Role for Transglutaminase?}

Whereas the corneocytes are the "bricks" of the surface barrier, ceramides and other lipids are extruded into the extracellular space to form the "mortar" [116,117]. Impermeability to water is provided by the extracellular lipids, as demonstrated by complete abrogation of the permeability barrier by the extraction of lipids $[118,119]$. Points of contact between corneocytes occur at villus-like structures, which at their tip contain corneodesmosomes, a complex consisting of cohesion proteins corneodesmosin, desmoglein 1 and desmocollin $1[120,121]$. Corneodesmosin is synthesized in the lower granular layer of the epidermis and is secreted from keratinocytes in vesicles as a glycoprotein [122,123]. In 
healthy skin, corneocytes are tightly stacked in the stratum corneum and express these villus-like structures mostly on their outermost rims (Figure 7B). Riethmüller et al. [124] discovered that these structures are approximately five-fold more numerous on homozygous $F L G^{-/-}$cells than on wild-type cells and cover the entire surface of the loosely packed mutant corneocytes (Figure 7A). The less tightly stacked stratum corneum of FLG ${ }^{-/-}$individuals is also characterized by a nearly two-fold increase in TEWL [124]. Although important for stability of the stratum corneum, corneodesmosomes do not inhibit water flow between cells. However, TEWL could possibly be reduced if adherence of corneocytes in filaggrin-deficient patients was increased.
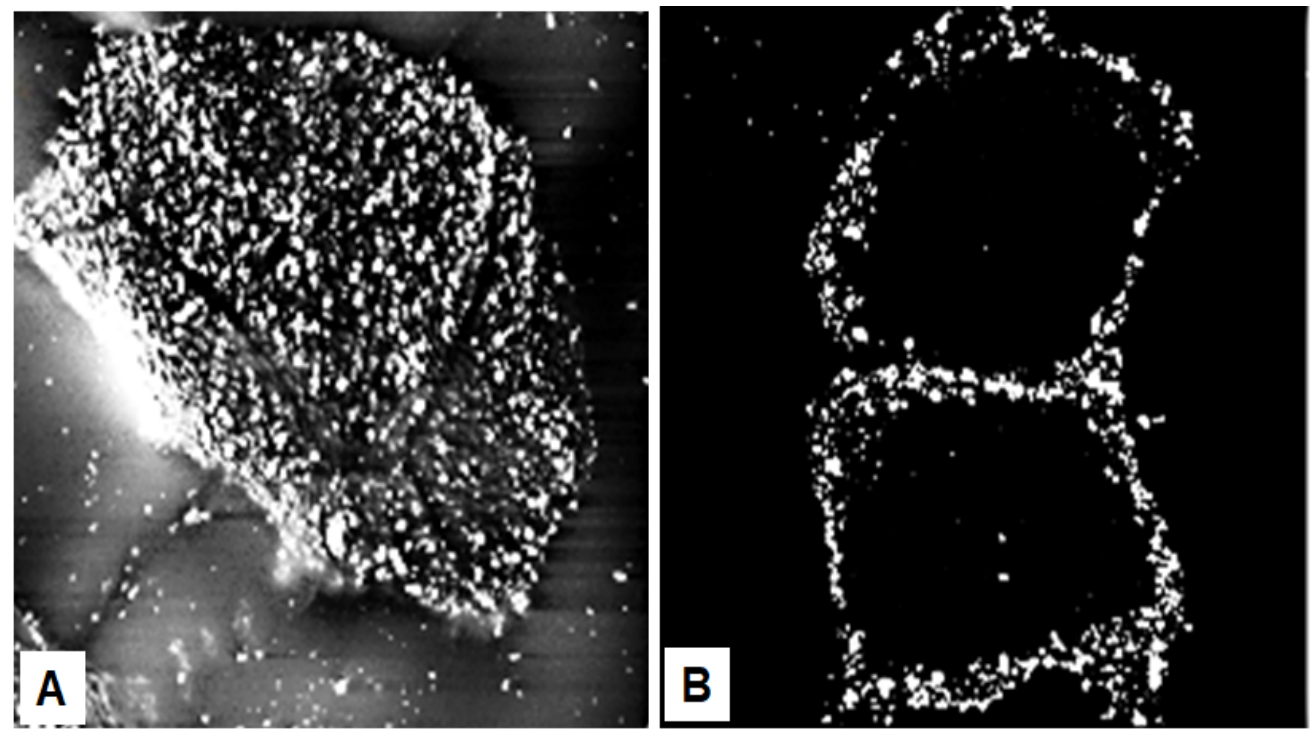

Figure 7. Corneodesmosomes. (A) Filaggrin-deficient $\left(F L G^{-/-}\right)$corneocytes from tape-stripped stratum corneum of patients with AD express corneodesmosin on villus-like projections that cover the entire cell surface. (B) In contrast, corneocytes from the tightly packed stratum corneum of wildtype $\left(F L G^{+/+}\right)$patients contain corneodesmosin mostly on lateral rims of the cells. The images were prepared by incubating corneocytes with anti-corneodesmosin antibodies followed by immunogold labeling and scanning electron microscopy [124] (with permission from S. Kezic).

The greater abundance of corneodesmosomes in filaggrin-deficient patients may be an attempt to compensate for the deficiency in filaggrin. Serine/glycine-rich loops in the N-terminal domain of corneodesmosin are exposed on the surface of the stratum corneum and are binding sites for colonization by Staphylococcus aureus and other pathogens in AD lesions [125]. Several lysine residues lie within the sequence near these loops and could serve as substrates for TGM2. An enzyme-bound thioester with the sidechain carboxyl group of a glutamate residue, formed in the first step of a cross-linking reaction, is attacked in the second step by an $\varepsilon$-amino group of a lysine residue in a protein to form $\varepsilon(\gamma$-glutamyl)lysine isopeptide bonds. Seemingly any lysine $\varepsilon$-amino group will enter the second step, but the enzyme is very specific for the glutamine residue, even when the protein is rich in glutamine. The sequences glutamine- $X$ (any amino acid)proline (QXP) and QXXQ are preferred substrates for TGM2, whereas QP or QXXP are not favorable substrates for the enzyme [126,127]. The paucity of accessible glutamine residues may minimize the number of cross-links between corneocytes. To overcome this restriction, a glutamine-containing, multivalent peptide, svL4 [128], which is a substrate for TGM2 (unpublished data), could provide 'lysine-peptide-lysine' cross-links between these corneocytes and thereby potentially tighten the surface barrier, as proposed in Figure 8. 


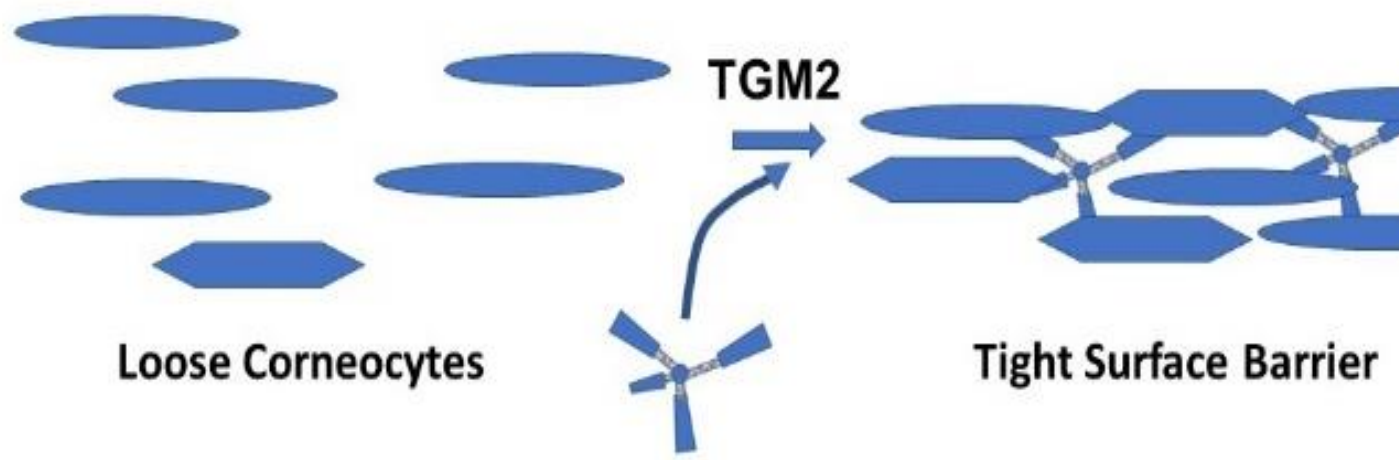

Figure 8. Model for the role of a tetravalent peptide in facilitating cross-linking of corneocytes by TGM2.

This approach could possibly be an effective treatment of necrotic lesions in severe cases of AD and for the repair of wounds. Additional cross-links between corneocytes may also resist excessive desquamation. Restoration of the surface barrier would allow the epidermal $\mathrm{Ca}^{2+}$ gradient to reform, which is critical for keratinocyte differentiation and healthy skin $[43-46,105,129]$.

This brief review provides an account of the intensive path of research, which in a relatively short period of time since its humble beginnings has achieved a level of understanding of cornification of the skin that is making a significant impact on quality of life.

Author Contributions: J.K.H. wrote the article with editing support from L.L.E.; L.L.E. discovered and characterized the peptide svL4. All authors have read and agreed to the published version of the manuscript.

Funding: This work was supported by Susavion Biosciences, Inc. and received no external funding. The sponsors had no role in the design, collection, analysis or interpretation of data, the writing of this article or the decision to submit it for publication.

Institutional Review Board Statement: Not applicable.

Informed Consent Statement: Not applicable.

Data Availability Statement: Not applicable.

Conflicts of Interest: J.K.H. and L.L.E. declare that they are cofounders of Susavion Biosciences, Inc., in which they hold shares.

\section{References}

1. Holbrook, K.A. Biologic structure and function: Perspectives on morphologic approaches to the study of the granular layer keratinocyte. J. Investig. Dermatol. 1989, 92, s84-s104. [CrossRef]

2. Rothman, S. Keratinization in historical perspective. In The Epidermis; Montagna, W., Lobitz, W.C., Jr., Eds.; Academic Press: New York, NY, USA, 1964; pp. 1-14.

3. Burgdorf, W.H.C.; Bickers, D.R. The scientific legacy of Stephen Rothman. J. Investig. Dermatol. 2015, 135, 954-959. [CrossRef] [PubMed]

4. Hoober, J.K. The Differential Incorporation of Amino Acids (In Vivo) into Proteins of the Newborn Rat Epidermis. Ph.D. Thesis, University of Michigan, Ann Arbor, MI, USA, 1965.

5. Reaven, E.P.; Cox, A.J., Jr. The histochemical localization of histidine in the human epidermis and its relationship to zinc binding. J. Histochem. Cytochem. 1963, 11, 782-790. [CrossRef]

6. Reaven, E.P.; Cox, A.J. Histidine and keratinization. J. Investig. Dermatol. 1965, 45, 422-431. [CrossRef] [PubMed]

7. Reaven, E.P.; Cox, A.J. Binding of zinc by the transitional layer of the epidermis. J. Investig. Dermatol. 1962, $39,133-137$.

8. Pauly, H. Über die Konstitution des Histidins. I. Mitteilung. Z. Physiol. Chem. Hoppe-Seyler 1904, 42, 508-518. [CrossRef]

9. Fukuyama, K.; Bernstein, I. Autoradiographic Studies of the Incorporation of Thymidine-H3into Deoxyribonucleic Acid in the Skin of Young Rats1. J. Investig. Dermatol. 1961, 36, 321-326. [CrossRef]

10. Fukuyama, K.; Bernstein, I.A. Site of synthesis of ribonucleic acid in mammalian epidermis. J. Investig. Dermatol. 1963, 41, 47-52. [CrossRef]

11. Fukuyama, K.; Nakamura, T.; Bernstein, I.A. Differentially localized incorporation of amino acids in relation to epidermal keratinization in the newborn rat. Anat. Rec. 1965, 152, 525-535. [CrossRef] 
12. Fukuyama, K.; Epstein, W.L. Ultrastructural autoradiographic studies of keratohyalin granule formation. J. Investig. Dermatol. 1967, 49, 595-604. [CrossRef]

13. Fukuyama, K.; Marshburn, I.; Epstein, W.L. Histidine-rich protein in developing rat epidermis. Dev. Biol. 1981, 81, 201-207. [CrossRef]

14. Bernstein, I.A.; Chakrabarti, S.G.; Kumaroo, K.K.; Sibrack, L.A. Synthesis of protein in the mammalian epidermis. I. Investig. Dermatol. 1970, 55, 291-302. [CrossRef] [PubMed]

15. Hoober, J.K.; Bernstein, I.A. Studies on the mechanism of the localized incorporation of glycine-H3 in newborn rat epidermis Fed. Proc. 1963, 22, 238.

16. Hoober, J.K.; Bernstein, I.A. Protein synthesis related to epidermal differentiation. Proc. Natl. Acad. Sci. USA 1966, 56, 594-601. [CrossRef]

17. Gumucio, J.; Feldkamp, C.; Bernstein, I.A. Studies on localization of "histidine-rich" peptide material present in epidermis of the newborn rat. J. Investig. Dermatol. 1967, 49, 545-551. [CrossRef] [PubMed]

18. Voorhees, J.J.; Siba, M.D.; Chakrabarti, G.; Bernstein, I.A. The metabolism of "histidine-rich" protein in normal and psoriatic keratinization. J. Investig. Dermatol. 1968, 51, 344-354. [CrossRef]

19. Ball, R.D.; Walker, G.K.; Bernstein, I.A. Histidine-rich proteins as molecular markers of epidermal differentiation. J. Biol. Chem. 1978, 253, 5861-5868. [CrossRef]

20. Ugel, A.R. Studies on isolated aggregating oligoribonucleoproteins of the epidermis with histochemical and morphological characteristics of keratohyalin. J. Cell Biol. 1971, 49, 405-422. [CrossRef]

21. Ugel, A.R.; Idler, W. Further characterization of bovine keratohyalin. J. Cell Biol. 1972, 52, 453-464. [CrossRef]

22. Sibrack, L.A.; Gray, R.; Bernstein, I. Localization of the Histidine-Rich Protein in Keratohyalin: A Morphologic and Macromolecular Marker in Epidermal Differentiation. J. Investig. Dermatol. 1974, 62, 394-405. [CrossRef]

23. Balmain, A.; Loehren, D.; Alonso, A.; Goerttler, K. Protein synthesis during fetal development of mouse epidermis. II. Biosynthesis of histidine-rich and cystine-rich proteins in vitro and in vivo. Develop. Biol. 1979, 73, 338-344. [CrossRef]

24. Balmain, A.; Loehren, D.; Fischer, J.; Alonso, A. Protein synthesis during fetal development of mouse epidermis: I. The appearance of "histidine-rich protein". Dev. Biol. 1977, 60, 442-452. [CrossRef]

25. Brown, S.J.; McLean, W.I. One Remarkable Molecule: Filaggrin. J. Investig. Dermatol. 2012, 132, 751-762. [CrossRef] [PubMed]

26. Dale, B.A. Purification and chaaracterization of a basic protein from the stratum corneum of mammalian epidermis. Biochem. Biophys. Acta 1977, 491, 193-204. [PubMed]

27. Steinert, P.M.; Cantieri, J.S.; Teller, D.C.; Lonsdale-Eccles, J.D.; Dale, B.A. Characterization of a class of cationic proteins that specifically interact with intermediate filaments. Proc. Natl. Acad. Sci. USA 1981, 78, 4097-4101. [CrossRef] [PubMed]

28. Harding, C.R.; Scott, I.R. Histidine-rich proteins (filaggrins): Structural and functional heterogeneity during epidermal differentiation. J. Mol. Biol. 1983, 170, 651-673. [CrossRef]

29. Steinert, P.M.; Roop, D.R. Molecular and cellular biology of intermediate filaments. Ann. Rev. Biochem. 1988, 57, 593-625. [CrossRef]

30. Fuchs, E.; Green, H. Changes in keratin gene expression during terminal differentiation of the keratinocyte. Cell 1980, 19, 1033-1042. [CrossRef]

31. Meek, R.L.; Lonsdale-Eccles, J.D.; Dale, B.A. Epidermal filaggrin is synthesized on a large messenger ribonucleic acid as a high-molecular-weight precursor. Biochemistry 1983, 22, 4867-4871. [CrossRef]

32. Lonsdale-Eccles, J.D.; Haugen, J.A.; Dale, B.A. A phosphorylated keratohyalin-derived precursor of epidermal stratum corneum basic protein. J. Biol. Chem. 1980, 255, 2235-2238. [CrossRef]

33. Fleckman, P.; Dale, B.A.; Holbrook, K.A. Profilaggrin, a High-Molecular-Weight Precursor of Filaggrin in Human Epidermis and Cultured Keratinocytes. J. Investig. Dermatol. 1985, 85, 507-512. [CrossRef]

34. Haydock, P.V.; Dale, B.A. The repetitive structure of the profilaggrin gene as demonstrated using epidermal profilaggrin cDNA J. Biol. Chem. 1986, 261, 12520-12525. [CrossRef]

35. Rothnagel, J.A.; Mehrel, T.; Idler, W.W.; Roop, D.R.; Steinert, P.M. The gene for mouse epidermal filaggrin precursor. J. Biol. Chem. 1987, 262, 15643-15648. [CrossRef]

36. McKinley-Grant, L.J.; Idler, W.W.; Bernstein, I.A.; Parry, D.A.; Cannizzaro, L.; Croce, C.M.; Huebner, K.; Lessin, S.R.; Steinert, P.M. Characterization of a cDNA clone encoding human filaggrin and localization of the gene to chromosome region 1q21. Proc. Natl. Acad. Sci. USA 1989, 86, 4848-4852. [CrossRef]

37. Resing, K.A.; Johnson, R.S.; Walsh, K.A. Characterization of protease processing sites during conversion of rat proflaggrin to filaggrin. Biochemistry 1993, 32, 10036-10045. [CrossRef]

38. Gan, S.Q.; McBride, O.W.; Idler, W.W.; Markova, N.; Steinert, P.M. Organization, structure, and polymorphisms of the human profilaggrin gene. Biochemistry 1990, 29, 9432-9440. [CrossRef]

39. Presland, R.B.; Haydock, P.V.; Fleckman, P.; Nirunsuksiri, W.; Dale, B.A. Characterization of the human epidermal profilaggrin gene. Genomic organization and identification of an S-100-like calcium binding domain at the amino terminus. J. Biol. Chem. 1992, 267, 23772-23781. [CrossRef]

40. Markova, N.G.; Marekov, L.N.; Chipev, C.C.; Gan, S.-Q.; Idler, W.W.; Steinert, P.M. Profilaggrin is a major epidermal calciumbinding protein. Mol. Cell. Biol. 1993, 13, 613-625. 
41. Rothnagel, J.A.; Steinert, P.M. The structure of the gene for mouse filaggrin and a comparison of the repeating units. J. Biol. Chem. 1990, 265, 1862-1865. [CrossRef]

42. Haydock, P.V.; Dale, B.A. Filaggrin, an Intermediate Filament-Associated Protein: Structural and Functional Implications from the Sequence of a cDNA from Rat. DNA Cell Biol. 1990, 9, 251-261. [CrossRef]

43. Bilkle, D.D.; Zie, Z.; Tu, C.-L. Calcium regulation of keratinocyte differentiation. Expert Rev. Endocrinol. Metab. $2012,7,461-472$. [CrossRef]

44. Lee, S.E.; Lee, S.H. Skin barrier and calcium. Ann. Dermatol. 2018, 30, 265-275. [CrossRef]

45. Lee, A.-Y. Molecular Mechanism of Epidermal Barrier Dysfunction as Primary Abnormalities. Int. J. Mol. Sci. 2020, $21,1194$. [CrossRef]

46. Mauro, T.; Elias, P.; Cullander, C.; Bench, G.; Sidderas-Haddad, E.; Feingold, K. Acute Barrier Perturbation Abolishes the Ca2+ and K+ Gradients in Murine Epidermis: Quantitative Measurement Using PIXE. J. Investig. Dermatol. 1998, 111, $1198-1201$. [CrossRef]

47. Aho, S.; Harding, C.R.; Lee, J.-M.; Meldrum, H.; Bosko, C.A. Regulatory Role for the Profilaggrin N-Terminal Domain in Epidermal Homeostasis. J. Investig. Dermatol. 2012, 132, 2376-2385. [CrossRef]

48. Sandilands, A.; Sutherland, C.; Irvine, A.D.; McLean, W.H.I. Filaggrin in the frontline: Role in skin barrier function and disease J. Cell Sci. 2009, 122, 1285-1294. [CrossRef]

49. Ishida-Yamamoto, A.; Senshu, T.; Eady, R.A.J.; Takahashi, H.; Shimizu, H.; Akiyama, M.; Iizukz, H. Sequential reorganization of cornified cell keratin filaments involving filaggrin-mediated compaction and keratin 1 dimination. J. Investig. Dermatol. 2002, 118, 282-287. [CrossRef]

50. Presland, R.; Kimball, J.R.; Kautsky, M.B.; Lewis, S.P.; Lo, C.Y.; Dale, B.A. Evidence for Specific Proteolytic Cleavage of the N-Terminal Domain of Human Profilaggrin During Epidermal Differentiation. J. Investig. Dermatol. 1997, 108, 170-178. [CrossRef]

51. Pearton, D.; Nirunsuksiri, W.; Rehemtulla, A.; Lewis, S.P.; Presland, R.; Dale, B.A. Proprotein convertase expression and localization in epidermis: Evidence for multiple roles and substrates. Exp. Dermatol. 2001, 10, 193-203. [CrossRef]

52. Matsui, T.; Miyamoto, K.; Kubo, A.; Kawasaki, H.; Ebihara, T.; Hata, K.; Tanahashi, S.; Ichinose, S.; Imoto, I.; Inazawa, J.; et al. SASPase regulates stratum corneum hydration through profilaggrin-to-filaggrin processing. EMBO Mol. Med. 2011, 3, 320-333. [CrossRef]

53. Leyvraz, C.; Charles, R.-P.; Rubera, I.; Guitard, M.; Rolman, S.; Breiden, B.; Sandhoff, K.; Hummler, E. The epidermal barrier function is dependent upon the serine protease CAP1/Prss8. J. Cell Biol. 2005, 170, 487-496. [CrossRef]

54. List, K.; Szabo, R.; Wertz, P.W.; Segre, J.; Haudenschild, C.C.; Kim, S.-Y.; Bugge, T.H. Loss of proteolytically processed filaggrin caused by epidermal deletion of Matriptase/MT-SP1. J. Cell Biol. 2003, 163, 901-910. [CrossRef]

55. Hsu, C.-Y.; Henry, J.; Raymond, A.-A.; Méchin, M.-C.; Pendaries, V.; Nassar, D.; Simon, M.; Serre, G.; Paul, C.; Takahara, H.; et al Deimination of human filaggrin-2 promotes its proteolysis by Calpain1. J. Biol. Chem. 2011, 286, 23222-23233. [CrossRef]

56. Hoste, E.; Kemperman, P.; Devos, M.; Denecker, G.; Kezic, S.; Yau, N.; Gilbert, B.; Lippens, S.; De Groote, P.; Roelandt, R.; et al. Caspase-14 Is Required for Filaggrin Degradation to Natural Moisturizing Factors in the Skin. J. Investig. Dermatol. 2011, 131, 2233-2241. [CrossRef]

57. Kamata, Y.; Taniguchi, A.; Yamamoto, M.; Nomura, J.; Ishihara, K.; Takahara, H.; Hibino, T.; Takeda, A. Neutral Cysteine Protease Bleomycin Hydrolase Is Essential for the Breakdown of Deiminated Filaggrin into Amino Acids. J. Biol. Chem. 2009, 284, 12829-12836. [CrossRef]

58. Hanson, K.M.; Simon, J.D. Epidermal trans-urocanic acid and the UV-A-induced photoaging of the skin. Proc. Natl. Acad. Sci. USA 1998, 95, 10576-10578. [CrossRef]

59. Gibbs, N.K.; Norval, M. Urocanic Acid in the Skin: A Mixed Blessing? J. Investig. Dermatol. 2011, 131, 14-17. [CrossRef]

60. Rawlings, A.V.; Harding, C.R. Moisturization and skin barrier function. Dermatol. Ther. 2004, 17, 43-48. [CrossRef]

61. Kezic, S.; Kemperman, P.M.; Koster, E.S.; de Jongh, C.M.; Thio, H.B.; Campbell, L.E.; Irvine, A.; McLean, W.H.I.; Puppels, G.J.; Caspers, P.J. Loss-of-Function Mutations in the Filaggrin Gene Lead to Reduced Level of Natural Moisturizing Factor in the Stratum Corneum. J. Investig. Dermatol. 2008, 128, 2117-2119. [CrossRef]

62. Kezic, S.; Novak, N.; Jakasa, I.; Jungersted, J.M.; Simon, M.; Brandner, J.M.; Middelkamp-Hup, M.A.; Weidinger, S. Skin barrier in atopic dermatitis. Front. Biosci. 2014, 19, 542-556. [CrossRef]

63. De Veer, S.J.; Furio, L.; Harris, J.M.; Hovnanian, A. Proteases: Common culprits in human skin disorders. Trends Mol. Med. 2014, 20, 166-178. [CrossRef]

64. Smith, F.J.D.; Irvine, A.; Terron-Kwiatkowski, A.; Sandilands, A.; Campbell, L.E.; Zhao, Y.; Liao, H.; Evans, A.T.; Goudie, D.R.; Lewis-Jones, S.; et al. Loss-of-function mutations in the gene encoding filaggrin cause ichthyosis vulgaris. Nat. Genet. 2006, 38, 337-342. [CrossRef]

65. Irvine, A.; McLean, W.H.I.; Leung, D.Y. Filaggrin Mutations Associated with Skin and Allergic Diseases. N. Engl. J. Med. 2011, 365, 1315-1327. [CrossRef]

66. McLean, W.H.I. Filaggrin failure-From ichthyosis vulgaris to atopic eczema and beyond. Br. J. Dermatol. 2016, 175 (Suppl. S2), 4-7. [CrossRef]

67. Salama, R.H.; Rasheed, Z.; Ahmed, A.A.; Bin Saif, G.A.; Elkholy, M.M.; El-Moniem, A.E.A.; Salem, T.; Zedan, K.; Al Robaee, A.A.; Alzolibani, A.A. Missense, silent, non-sense and frame-shift mutations in exon 3 of the filaggrin gene in patients with bronchial asthma, atopic dermatitis, allergic rhinitis and mixed atopy. Nucleosides Nucleotides Nucleic Acids 2021, 40, 357-367. [CrossRef] 
68. O'Regan, G.M.; Sandilands, A.; McLean, W.H.I.; Irvine, A.D. Filaggrin in atopic dermatitis. J. Allergy Clin. Immunol. 2008, 122, 689-693. [CrossRef]

69. Osawa, R.; Akiyama, M.; Shimizu, H. Filaggrin Gene Defects and the Risk of Developing Allergic Disorders. Allergol. Int. 2011, 60, 1-9. [CrossRef]

70. Rodríguez, E.; Illig, T.; Weidinger, S. Filaggrin loss-of-function mutations and association with allergic diseases. Pharmacogenomics 2008, 9, 399-413. [CrossRef]

71. Bin, L.; Malley, C.; Taylor, P.; Boorgula, M.P.; Chavan, S.; Daya, M.; Mathias, M.; Shankar, G.; Rafaels, N.; Vergara, C.; et al Whole genome sequencing identifies novel genetic mutations in patients with eczema herpeticum. Allergy 2021, 76, $2510-2523$. [CrossRef]

72. Esparza-Gordillo, J.; Matanovic, A.; Marenholz, I.; Bauerfeind, A.; Rohde, K.; Nemat, K.; Lee-Kirsch, M.-A.; Nordenskjöld, M.; Winge, M.C.G.; Keil, T.; et al. Maternal Filaggrin Mutations Increase the Risk of Atopic Dermatitis in Children: An Effect Independent of Mutation Inheritance. PLoS Genet. 2015, 11, e1005076. [CrossRef]

73. Butler, D.C.; Simpson, E.; Guttman-Yassky, E.; Eichenfield, L.F.; Golant, A.K.; Koo, J.Y.M.; Armstrong, A.W.; Alexis, A.F.; Lio, P.A.; Marson, J.W.; et al. The atopic dermatitis spectrum disorder. Recognizing the clinical heterogeneity in patients with atopic related skin conditions in order to improve therapeutic decision-making and outcomes: An expert panel consensus statement. J. Dermatol. Treat. 2021, 33, 1-3. [CrossRef] [PubMed]

74. Shaw, T.E.; Currie, G.P.; Koudelka, C.W.; Simpson, E.L. Eczema Prevalence in the United States: Data from the 2003 National Survey of Children's Health. J. Investig. Dermatol. 2011, 131, 67-73. [CrossRef] [PubMed]

75. Nutten, S. Atopic Dermatitis: Global Epidemiology and Risk Factors. Ann. Nutr. Metab. 2015, 66 (Suppl. S1), 8-16. [CrossRef] [PubMed]

76. McAleer, M.A.; Jakasa, I.; Raj, N.; O’Donnell, C.P.F.; Lane, M.E.; Rawlings, A.V.; Irvine, A.D.; Voegeli, R.; McLean, W.H.I.; Kezic, S. Early-life regional and temporal variation in filaggrin-derived moisturizing factor, filaggrin-processing enzyme activity, corneocyte phenotypes and plasmin activity: Implications for atopic dermatitis. Br. J. Dermatol. 2018, 179, 431-441. [CrossRef]

77. Werfel, T.; Allam, J.-P.; Biedermann, T.; Eyerich, K.; Gilles, S.; Guttman-Yassky, E.; Akdis, C.A.; Bieber, T.; Knol, E.; Lauener, R.; et al. Cellular and molecular immunologic mechanisms in patients with atopic dermatitis. J. Allergy Clin. Immunol. 2016, 138, 336-349. [CrossRef]

78. Sözener, Z.C.; Cevhertas, L.; Nadeau, K.; Akdis, M.; Akdis, C.A. Environmental factors in epithelial barrier dysfunction J. Allergy Clin. Immunol. 2020, 145, 1517-1528. [CrossRef]

79. Peng, W.; Novak, N. Pathogenesis of atopic dermatitis. Clin. Exp. Allergy 2015, 45, 566-574. [CrossRef]

80. Thyssen, J.P.; Kezic, S. Causes of epidermal filaggrin reduction and their role in the pathogenesis of atopic dermatitis. J. Allergy Clin. Immunol. 2014, 134, 792-799. [CrossRef]

81. Dębińska, A. New Treatments for Atopic Dermatitis Targeting Skin Barrier Repair via the Regulation of FLG Expression. J. Clin. Med. 2021, 10, 2506. [CrossRef]

82. Jin, H.; He, R.; Oyoshi, M.; Geha, R.S. Animal models of atopic dermatitis. J. Investig. Dermatol. 2009, 129, 31-40. [CrossRef]

83. Martel, B.C.; Lovato, P.; Bäumer, W.; Olivry, T. Translational Animal Models of Atopic Dermatitis for Preclinical Studies. Yale J. Biol. Med. 2017, 90, 389-402. [PubMed]

84. Stout, T.E.; McFarland, T.; Mitchell, J.C.; Appukuttan, B.; Stout, J.T. Recombinant Filaggrin Is Internalized and Processed to Correct Filaggrin Deficiency. J. Investig. Dermatol. 2014, 134, 423-429. [CrossRef] [PubMed]

85. Kawasaki, H.; Nagao, K.; Kubo, A.; Hata, T.; Shimizu, A.; Mizuno, H.; Yamada, T.; Amagai, M. Altered stratum corneum barrier and enhanced percutaneous immune responses in filaggrin-null mice. J. Allergy Clin. Immunol. 2012, 129, 1538-1546.e6. [CrossRef]

86. Van Ruissen, F.; Le, M.; Carroll, J.M.; van der Valk, P.G.; Schalkwijk, J. Differential Effects of Detergents on Keratinocyte Gene Expression. J. Investig. Dermatol. 1998, 110, 358-363. [CrossRef] [PubMed]

87. Törma, H.; Lindberg, M.; Berne, B. Skin barrier disruption by sodium lauryl sulfate-exposure alters the expression of involucrin transglutamnase 1, profilaggrin, and kallikreins during the repair phase in human skin in vivo. J. Investig. Dermatol. 2008, 128, 1212-1219. [CrossRef] [PubMed]

88. Huang, H.-C.; Chang, T.-M. Ceramide 1 and ceramide 3 act synergistically on skin hydration and the transepidermal water loss of sodium lauryl sulfate-irritated skin. Int. J. Dermatol. 2008, 47, 812-819. [CrossRef] [PubMed]

89. Kasparek, P.; Ileninova, Z.; Zbodakova, O.; Kanchev, I.; Benada, O.; Chalupsky, K.; Sedlacek, R.; Brattsand, M.; Beck, I.M. KLK5 and KLK7 ablation fully rescues letahlity of Netherton syndrome-like phenotype. PLoS Genet. 2017, 13, e1006566. [CrossRef]

90. Furio, L.; Pampalakis, G.; Michael, I.; Nagy, A.; Sotiropoulou, G.; Hovnanian, A. KLK5 Inactivation Reverses Cutaneous Hallmarks of Netherton Syndrome. PLoS Genet. 2015, 11, e1005389. [CrossRef]

91. Miyai, M.; Matsumoto, Y.; Yamanishi, H.; Yamamoto-Tanaka, M.; Tsuboi, R.; Hibino, T. Keratinocyte-specific mesotrypsin contributes to the desquamation process via kallikrein activation and LEKT1 degradation. J. Investig. Dermatol. 2014, 134, 1665-1674. [CrossRef]

92. Briot, A.; Deraison, C.; Lacroix, M.; Bonnart, C.; Robin, A.; Besson, C.; Hovnanian, A.; Dubus, P. Kalikrein 5 induces atopic dermatitis-like lesions through PAR2-mediated thymic stromal lymphopoietin expression in Netherton syndrome. J. Exp. Med. 2009, 206, 1135-1147. [CrossRef] 
93. Zhao, Y.; Terron-Kwiatkowski, A.; Liao, H.; Lee, S.P.; Allen, M.H.; Hull, P.R.; Campbell, L.E.; Trembath, R.C.; Capon, F.; Griffiths, C.E.; et al. Filaggrin Null Alleles Are Not Associated with Psoriasis. J. Investig. Dermatol. 2007, 127, 1878-1882. [CrossRef] [PubMed]

94. Hüffmeier, U.; Traupe, H.; Oji, V.; Lascorz, J.; Ständer, M.; Lohmann, J.; Reis, A.; Wendler, J.; Burkhardt, H. Loss-of-function variants of the filaggrin gene are not major suseptibility factors for psoriasis vulgaris or psoriatic arthritis in German patients. J. Investig. Dermatol. 2007, 127, 1367-1370. [CrossRef] [PubMed]

95. Kalinin, A.; Marekov, L.N.; Steinert, P.M. Assembly of the epidermal cornified cell envelope. J. Cell Sci. 2001, 114, 3069-3070. [CrossRef] [PubMed]

96. Candi, E.; Schmidt, R.; Melino, G. The cornified envelope: A model of cell death in the skin. Nat. Rev. Mol. Cell Biol. 2005, 6, 328-340. [CrossRef] [PubMed]

97. Eckert, R.L.; Green, H. Structure and evolution of the human involucrin gene. Cell 1986, 46, 583-589. [CrossRef]

98. Eckert, R.L.; Sturniolo, M.T.; Broome, A.-M.; Ruse, M.; Rorke, E.A. Transglutaminase Function in Epidermis. J. Investig. Dermatol. 2005, 124, 481-492. [CrossRef]

99. Simon, M.; Green, H. The glutamine residues reactive in transglutaminase-catalyzed cross-linking of involucrin. J. Biol. Chem. 1988, 263, 18093-18098. [CrossRef]

100. Ishitsuka, Y.; Roop, D.R. Loricrin: Past, present, and future. Int. J. Mol. Sci. 2020, 21, 2271. [CrossRef]

101. Steinert, P.M.; Marekov, L.N. The Proteins Elafin, Filaggrin, Keratin Intermediate Filaments, Loricrin, and Small Proline-rich Proteins 1 and 2 Are Isodipeptide Cross-linked Components of the Human Epidermal Cornified Cell Envelope. J. Biol. Chem. 1995, 270, 17702-17711. [CrossRef]

102. Matsuki, M.; Yamashita, F.; Ishida-Yamamoto, A.; Yamada, K.; Kinoshita, C.; Fushiki, S.; Yamanishi, K.; Ueda, E.; Tabata, K.; Okabe, M.; et al. Defective stratum corneum and early neonatal death in mice lacking the gene for transaminase 1 (keratinocyte transglutamase). Proc. Natl. Acad. Sci. USA 1998, 95, 1044-1049. [CrossRef]

103. Liedén, A.; Winge, M.C.G.; Sääf, A.; Kockum, I.; Ekelund, E.; Rodriguez, E.; Fölster-Holst, R.; Franke, A.; Illig, T.; Tengvall-Linder, M.; et al. Genetic Variation in the Epidermal Transglutaminase Genes Is Not Associated with Atopic Dermatitis. PLoS ONE 2012, 7, e49694. [CrossRef] [PubMed]

104. Su, H.; Luo, Y.; Sun, J.; Liu, X.; Ling, S.; Xu, B.; Zhang, Y.; Liu, J.; Li, W.; Wang, B.; et al. Transglutaminase 3 Promotes Skin Inflammation in Atopic Dermatitis by Activating Monocyte-Derived Dendritic Cells via DC-SIGN. J. Investig. Dermatol. 2020, 140, 370-379. [CrossRef] [PubMed]

105. Griffin, M.; Casadio, R.; Bergamini, C.M. Transglutaminases: Nature's biological glues. Biochem. J. 2002, 368, 377-396. [CrossRef]

106. Chou, C.-Y.; Streets, A.J.; Watson, P.F.; Huang, L.; Verderio, E.A.; Johnson, T.S. A Crucial Sequence for Transglutaminase Type 2 Extracellular Trafficking in Renal Tubular Epithelial Cells Lies in Its N-terminal $\beta$-Sandwich Domain. J. Biol. Chem. 2011, 286, 27825-27835. [CrossRef] [PubMed]

107. Zemskov, E.A.; Mikhailenko, I.; Hsia, R.-C.; Zaritskaya, L.; Belkin, A.M. Unconventional Secretion of Tissue Transglutaminase Involves Phospholipid-Dependent Delivery into Recycling Endosomes. PLoS ONE 2011, 6, e19414. [CrossRef]

108. Nurminskaya, M.V.; Belkin, A.M. Cellular Functions of Tissue Transglutaminase. Int. Rev. Cell. Mol. Biol. 2012, $294,1-97$. [CrossRef]

109. Telei, D.; Griffin, M. Tissue transaminase (TG2)—A wound response enzyme. Front. Biosci. 2006, 11, 867-882.

110. Stephens, P.; Grenard, P.; Aeschlimann, P.; Langley, M.; Blain, E.; Errington, R.; Kipling, D.; Thomas, D.; Aeschlimann, D. Crosslinking and G-protein functions of transglutaminase 2 contribute differentially to fibroblast wound healing responses. J. Cell Sci. 2004, 117, 3389-3403. [CrossRef]

111. Haroon, Z.A.; Hettasch, J.M.; Lai, T.-S.; Dewhirst, M.W.; Greenberg, C.S. Tissue transglutaminase is expressed, active, and directly involved in rat dermal wound healing and angiogenesis. FASEB J. 1999, 13, 1787-1795. [CrossRef]

112. Verderio, E.A.M.; Johnson, T.; Griffin, M. Tissue transglutaminase in normal and abnormal wound healing: Review article. Amino Acids 2004, 26, 387-404. [CrossRef]

113. Johnson, T.S.; Scholfield, C.I.; Parry, J.; Griffin, M. Induction of tissue transglutaminase by dexamethasone: Its correlation to receptor number and transglutaminase-mediated cell death in a series of malignant hamster fibrosarcomas. Biochem. J. 1998, 331, 105-112. [CrossRef] [PubMed]

114. Pinkas, D.; Strop, P.; Brunger, A.; Khosla, C. Transglutaminase 2 Undergoes a Large Conformational Change upon Activation PLoS ONE 2007, 5, e327. [CrossRef]

115. Mearns, B.; Nanda, N.; Michalieck, J.; Iismaa, S.; Graham, R. Impaired wound healing and altered fibroblast cytoskeletal dynamics in Gh knockout mice. Minerva Biotecnol. 2002, 14, 218.

116. Elias, P.M. Epidermal lipids, barrier function, and desquamation. J. Investig. Dermatol. 1983, 80, 544-549. [CrossRef] [PubMed]

117. Nemes, Z.; Steinert, P.M. Bricks and mortar of the epidermal barrier. Exp. Mol. Med. 1999, 31, 5-19. [CrossRef] [PubMed]

118. Grubauer, G.; Elias, P.M.; Feingold, K.R. Transepidermal water loss: The signal for recovery of barrier structure and function. J. Lipid Res. 1989, 30, 323-333. [CrossRef]

119. Elias, P.M.; Wakefield, J.S. Mechanisms of abnormal lamellar body secretion and the dysfunctional skin barrier in patients with atopic dermatitis. J. Allergy Clin. Immunol. 2014, 134, 781-791.e1. [CrossRef] 
120. Caubet, C.; Jonca, N.; Brattsand, M.; Guerrin, M.; Bernard, D.; Schmidt, R.; Egelrud, T.; Simon, M.; Serre, G. Degradation of Corneodesmosome Proteins by Two Serine Proteases of the Kallikrein Family, SCTE/KLK5/hK5 and SCCE/KLK7/hK7. J. Investig. Dermatol. 2004, 122, 1235-1244. [CrossRef]

121. Igawa, S.; Kishibe, M.; Honma, M.; Murakami, M.; Mizuno, Y.; Suga, Y.; Seishima, M.; Ohguchi, Y.; Akiyama, M.; Hirose, K.; et al. Aberrant distribution patterns of corneodesmosomal components of tape-stripped corneocytes in atopic dermatitis and related skin conditions (ichthyosis vulgaris, Netherton syndrome and peeling skin syndrome type B). J. Dermatol. Sci. 2013, 72, 54-60. [CrossRef]

122. Simon, M.; Montézin, M.; Guerrin, M.; Durieux, J.-J.; Serre, G. Characterization and Purification of Human Corneodesmosin, an Epidermal Basic Glycoprotein Associated with Corneocyte-specific Modified Desmosomes. J. Biol. Chem. 1997, 272, 31770-31776. [CrossRef]

123. Guerrin, M.; Simon, M.; Montézin, M.; Haftek, M.; Vincent, C.; Serre, G. Expression Cloning of Human Corneodesmosin Proves Its Identity with the Product of the S Gene and Allows Improved Characterization of Its Processing during Keratinocyte Differentiation. J. Biol. Chem. 1998, 273, 22640-22647. [CrossRef] [PubMed]

124. Riethmuller, C.; McAleer, M.A.; Koppes, S.A.; Abdayem, R.; Franz, J.; Haftek, M.; Campbell, L.E.; MacCallum, S.F.; McLean, W.I.; Irvine, A.D.; et al. Filaggrin breakdown products determine corneocyte conformation in patients with atopic dermatitis. J. Allergy Clin. Immunol. 2015, 136, 1573-1580.e2. [CrossRef] [PubMed]

125. Towell, A.M.; Feuillie, C.; Vitry, P.; Da Costa, T.M.; Mathelié-Guiniet, M.; Kezic, S.; Geoghegan, J.A.; Irvine, D.A.; Fleury, M.O.; McAleer, M.A.; et al. Staphylococcus aureus binds to the N-terminal region of corneodesmosin to adhere to the stratum corneum in atopic dermatitis. Proc. Natl. Acad. Sci. USA 2021, 118, e2014444118. [CrossRef] [PubMed]

126. Vader, L.W.; De Ru, A.; Van Der Wal, Y.; Kooy, Y.M.; Benckhuijsen, W.; Mearin, M.L.; Drijfhout, J.W.; van Veelen, P.; Koning, F. Specificity of Tissue Transglutaminase Explains Cereal Toxicity in Celiac Disease. J. Exp. Med. 2002, 195, 643-649. [CrossRef]

127. Fleckenstein, B.; Molberg, Ø.; Qiao, S.-W.; Schmid, D.G.; von der Mu“lbe, F.; Elgstøen, K.; Jung, G.; Sollid, L.M. Gliadin T Cell Epitope Selection by Tissue Transglutaminase in Celiac Disease. J. Biol. Chem. 2002, 277, 34109-34116. [CrossRef]

128. Eggink, L.L.; Roby, K.F.; Cote, R.; Hoober, J.K. An innovative immunotherapeutic strategy for ovarian cancer: CLEC10A and glycomimetic peptides. J. Immunother. Cancer 2018, 6, 28. [CrossRef]

129. Teshima, H.; Kato, M.; Tatsukawa, H.; Hitomi, K. Analysis of the expression of transglutaminases in the reconstructed human epidermis using a three-dimensional cell culture. Anal. Biochem. 2020,603, 113606. [CrossRef] 